\title{
Stratigraphic and Structural
}

Controls of Uranium

Deposits on Long

Mountain, South Dakota

GEOLOGICAL SURVEY BULLETIN 1063 -A

This report concerns work done on behalf of the U.S. Atomic Energy Commission and is published with the permission of the Commission

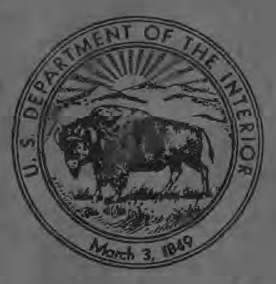


5

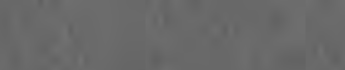

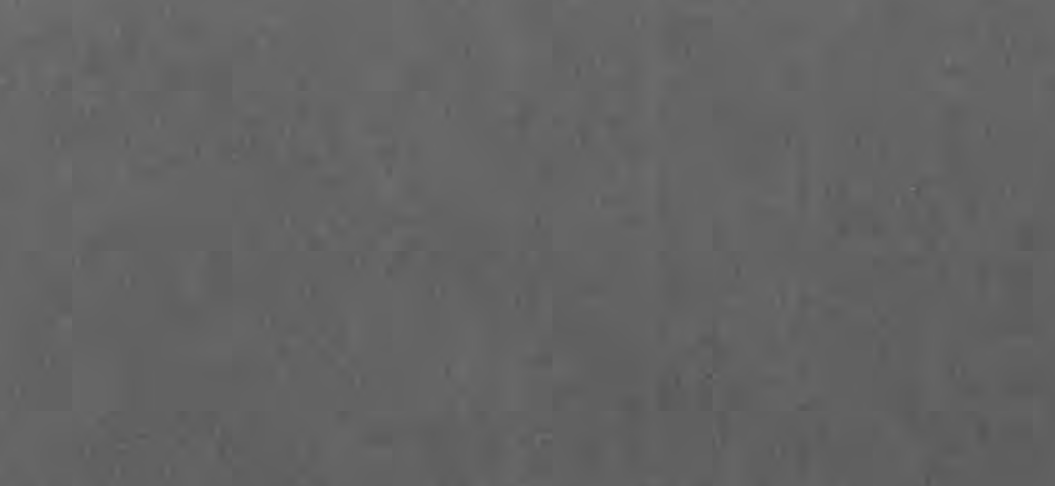

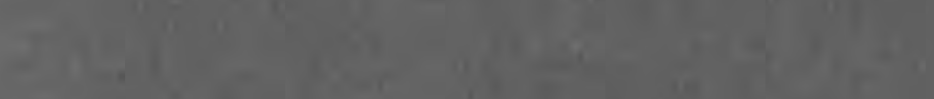

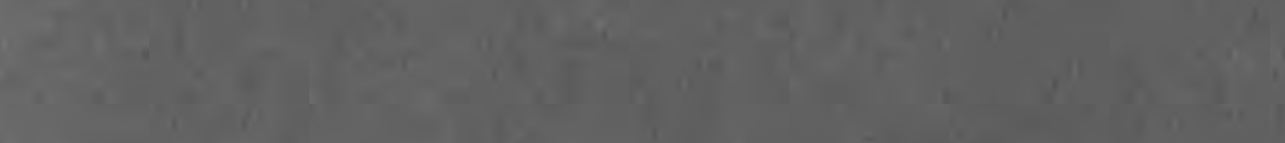

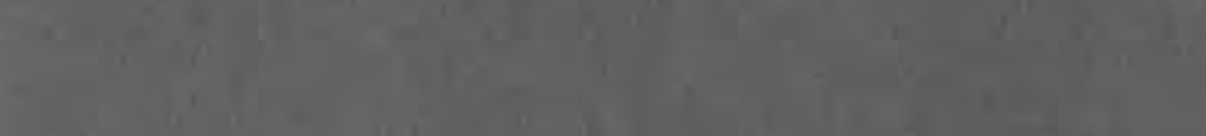

2.5
2

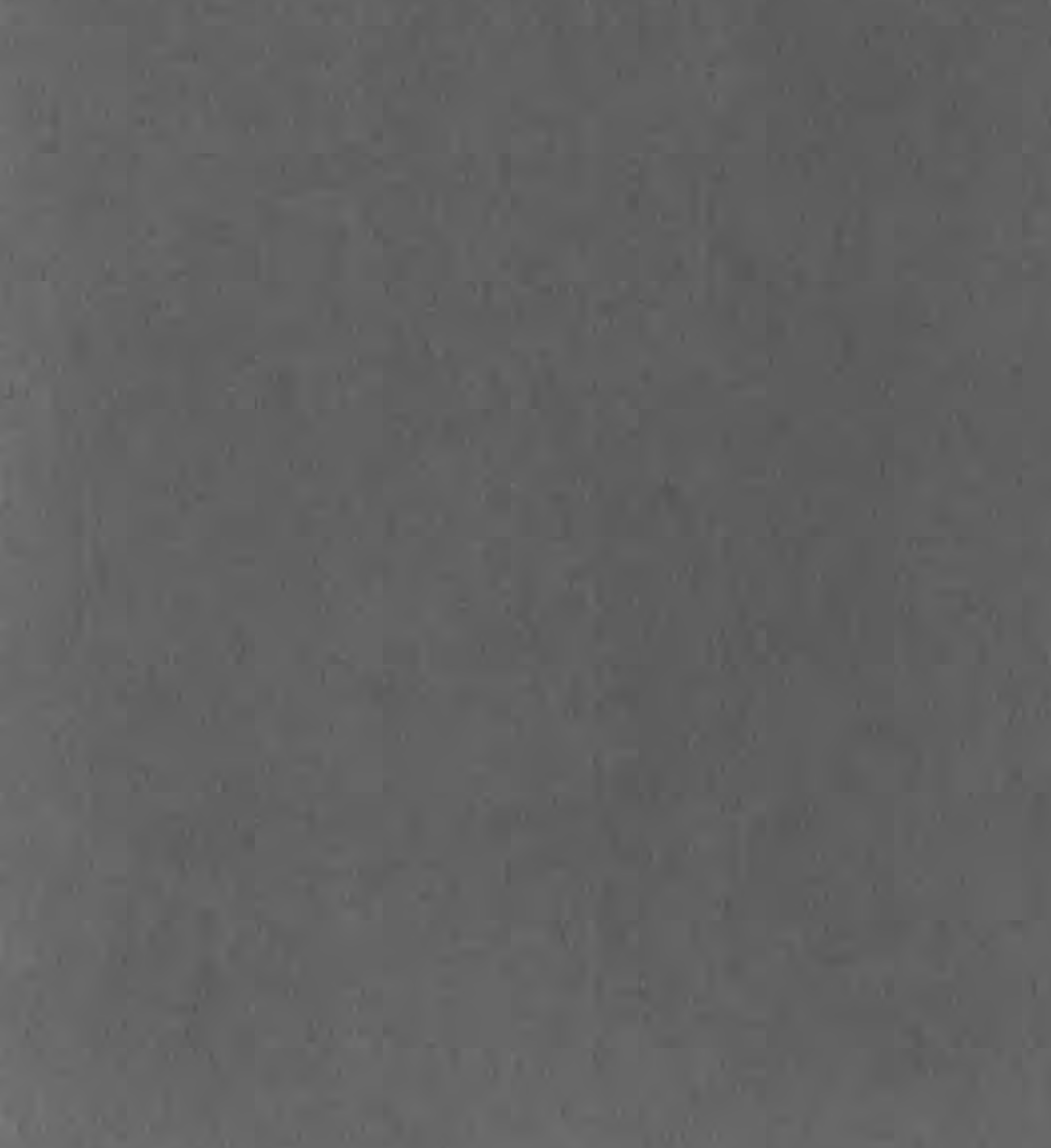




\section{Stratigraphic and Structural}

Controls of Uranium

\section{Deposits on Long}

\section{Mountain, South Dakota}

By WILLIAM A. BRADDOCK

GEOLOGY AND URANIUM DEPOSITS OF SOUTHERN BLACK HILLS

GEOLOGICAL SURVEY BULLETIN 1063-A

This report concerns work done on behalf of the U. S. Atomic Energy Commission and is published with the permission of the Commission

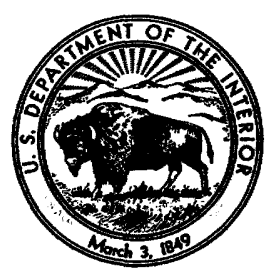




\title{
UNITED STATES DEPARTMENT OF THE INTERIOR
}

\author{
FRED A. SEATON, Secretary
}

\section{GEOLOGICAL SURVEY}

Thomas B. Nolan, Director 


\section{CONTENTS}

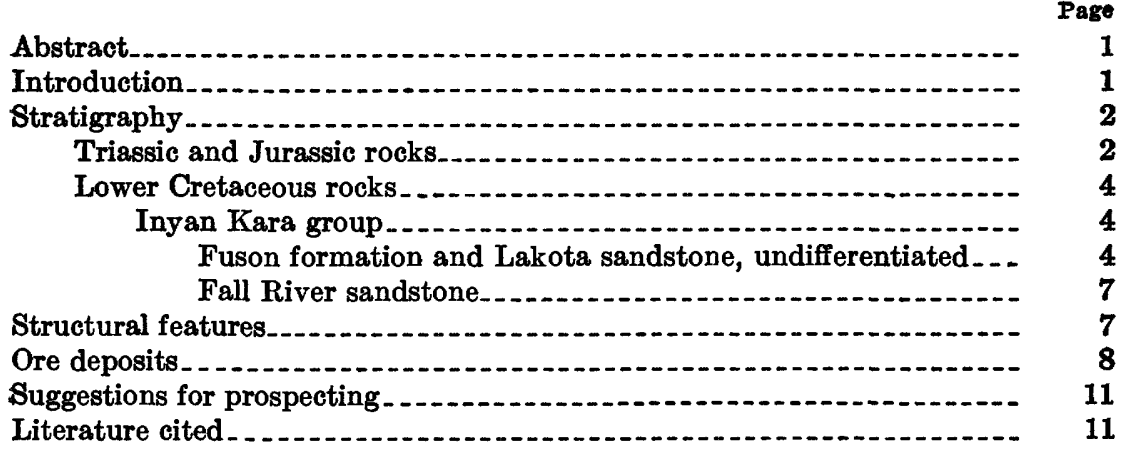

\section{IILUSTRATIONS}

[Plates 1-4 in pocket]

Plate 1. Geologic map of part of Long Mountain, Fall River County, S. Dak.

2. Correlation diagram, north part of Long Mountain, Fall River County, S. Dak., showing Lakota sandstone and Fuson formation, undifferentiated, overlying the Morrison formation.

3. Correlation diagram, middle part of Long Mountain, Fall River County, S. Dak., showing Lakota sandstone and Fuson formation, undifferentiated, overlying the Morrison formation.

4. Lithologic variations within the upper uraniferous sandstone of the Lakota sandstone and Fuson formation, undifferentiated.

Frgdre 1. Lithology of the Morrison formation.

2. Structure contour map, southern part of Long Mountain. Contours drawn on the top of the Morrison formation......

3. Structure contour map, southern part of Long Mountain. Contours drawn on the base of the upper uraniferous sandstone

4. Comparison of the vanadium content of the ore shipped from the lower and upper uraniferous sandstones. 



\title{
STRATIGRAPHIC AND STRUCTURAL CONTROLS OF URANIUM DEPOSITS ON LONG MOUNTAIN, SOUTH DAKOTA
}

\author{
By William A. Braddock
}

\begin{abstract}
Numerous occurrences of uranium have been found in the Long Mountain area, Fall River County, S. Dak. Correlation diagrams prepared from drill cores obtained from the U. S. Atomic Energy Commission indicate that the uranium is most abundant in two sandstone units, separated by mudstone in the undifferentiated Fuson formation and Lakota sandstone of Early Cretaceous age. The lower uraniferous unit is composed of thick beds of very fine to fine-grained sandstone with a few interfingering lentils of mudstone. The upper uraniferous unit is composed of interfingering beds of very fine-, fine-, and coarse-grained sandstone and mudstone.

The uranium deposits on Long Mountain and in the area to the west are most numerous in a northeastward-trending zone about a mile wide between two normal faults.

The sedimentary structures of the upper and lower mineralized sandstone between the faults have locally controlled the deposition of uranium and vanadium.
\end{abstract}

\section{INTRODUCTION}

The first uranium deposit to be discovered in the Black Hills was found on the Pictograph Mesa in Craven Canyon on the west side of Long Mountain, Fall River County, S. Dak., in June 1951. Homestake Mining Company, United States Vanadium Corporation and other prospectors found several deposits along the cliffs of Craven Canyon and on Long Mountain (Page and Redden, 1952). During 1952 and 1953 the U. S. Atomic Energy Commission drilled 198 diamond drill holes on Long Mountain. The cores from 86 holes were examined to determine the lithologic and structural features of the Lakota sandstone, and the relationship of these features to the uranium deposits. A geologic map of part of Long Mountain was prepared by Garland Gott, Henry Bell, William Braddock, and Dave Engstrom (see pl. 1). 
During the field work, personnel of the Hot Springs office of the Atomic Energy Commission provided drill-core data and assisted in other ways. This investigation was a part of the regional study being made by the Geological Survey on behalf of the Division of Raw Materials of the U. S. Atomic Energy Commission.

\section{STRATIGRAPHY}

The rocks in the immediate vicinity of Long Mountain are of sedimentary origin and range in age from Triassic to Cretaceous. The soft shale and sandstone of the Triassic and Jurassic formations have been eroded into a broad valley trending west to northwest across the northern part of the area. South of this valley the more resistant sandstone of the Lower Cretaceous forms northwestward-trending cuestas. Southward-draining tributaries of the Cheyenne River have cut through these cuestas to form steep-walled canyons separated by long northward-trending ridges. Long Mountain is such a ridge, and is bounded on the west side by Craven Canyon and on the east side by Red Canyon.

\section{TRIASSIC AND JURASSIC ROCKS}

The oldest rocks in the vicinity of Long Mountain are the red sandy shales and thin beds of gypsum of the Spearfish formation of Triassic age. This formation, about 500 feet thick, is well exposed in the large valley on the north side of Long Mountain.

The Sundance formation of Late Jurassic age, about 300 feet thick, crops out in Red and Craven Canyons. It is composed of red, yellow, and gray sandstone, gray shale, and thin beds of limestone.

The Sundance formation is overlain by the Morrison formation of Late Jurassic age, which crops out around the base of Long Mountain and extends down Craven Canyon to Pictograph Mesa where it is about 90 feet thick (see pl. 1). The lower part of the formation is composed of resistant beds of dense light-gray limestone interbedded with gray or greenish marl-stone; the upper part consists of gray to greenish claystone. Much of the claystone near the top of the formation is dark gray and resembles the gray mudstone in the Lakota and Fuson. The claystone beds of the Morrison formation are generally free of silt, have a waxy luster, and contain no sandstone lenses. By comparison, the mudstone beds in the overlying Lakota sandstone and Fuson formation, undifferentiated, are generally silty, have a dull luster, and contain thin irregular sandstone lenses. The thickness and lithologic features of the Morrison formation across Long Mountain are illustrated by figure 1; the formation is about 90 feet thick. At many localities landslides conceal the contact of the Morrison formation with the overlying Lakota sandstone. 


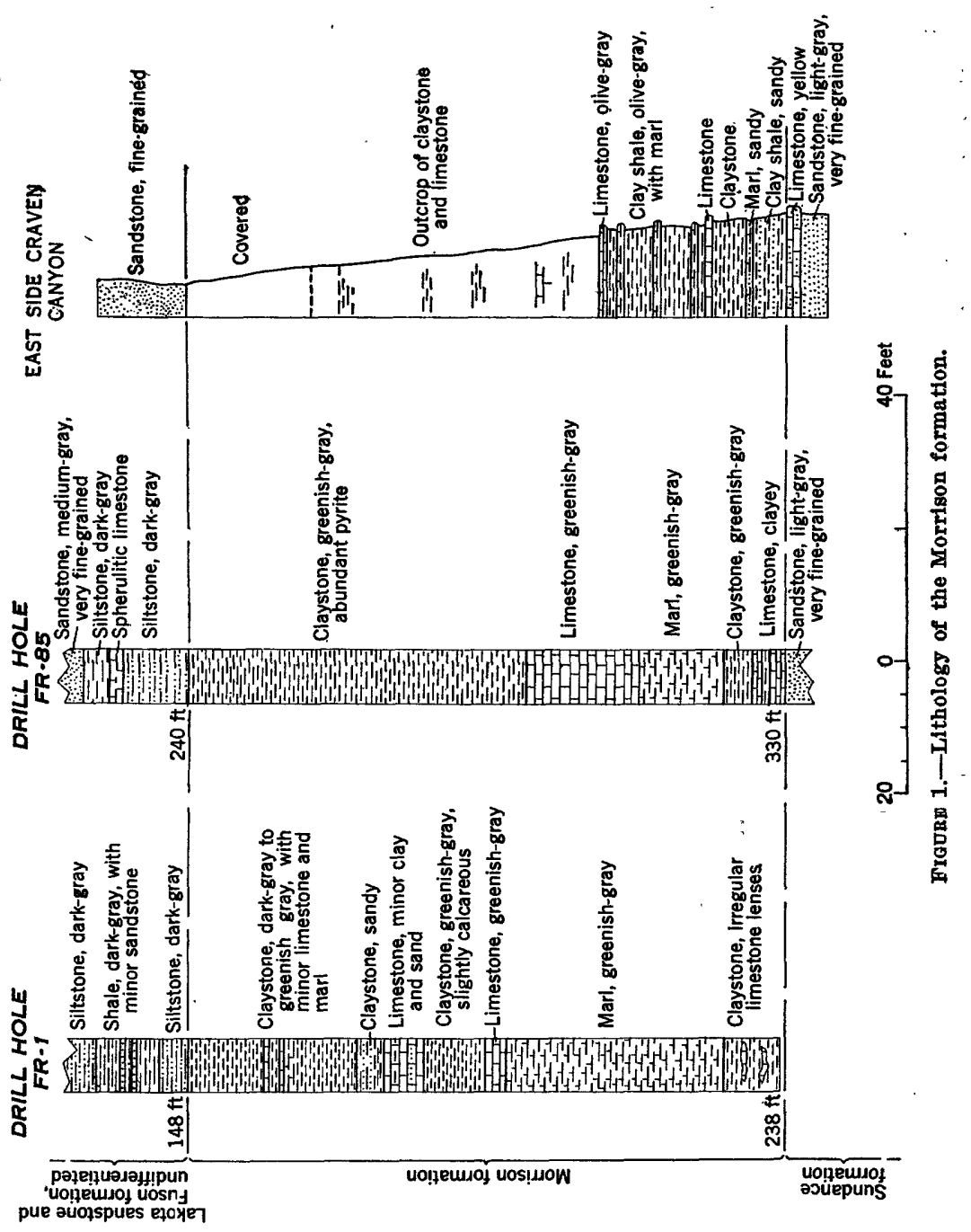




\section{LOWER CRETACEOUS ROCKS}

\section{INYAN KARA GROUP}

The Lower Cretaceous rocks were divided by Darton (1901) in ascending order into the Lakota sandstone, the Minnewaste limestone, the Fuson shale, and the Dakota sandstone. Russell (1927) recognized that the Dakota sandstone of the Black Hills was older than the Dakota of eastern Nebraska, and introduced the name Fall River sandstone for the rocks that Darton had mapped as the Dakota sandstone. Rubey (1931, and written communication) recognized the difficulty of delimiting the upper and lower contacts of the Fuson formation. He classified the Lakota, Fuson, and Fall River rocks as the Inyan Kara group, a group of rocks consisting of sandstone, minor beds of conglomerate, thin limestone beds, carbonaceous mudstone, noncarbonaceous variegated mudstone, and lignite. Since $1951 \mathrm{mem}-$ bers of the Atomic Energy Commission and of the Geological Survey have studied the Inyan Kara group in the Edgemont mining district. Results of this work indicate that the Fuson formation and Lakota sandstone are not separable in those areas where the Minnewaste limestone is absent. As the Minnewaste limestone is absent in the Long Mountain area, the Fuson and Lakota formations have not been differentiated on plate 1 .

\section{FUSON FORMATION AND IAKOTA SANDSTONE, UNDIFTERENTIATED}

The undifferentiated Fuson and Lakota formations are about 370 feet thick in the Long Mountain area. A section measured on the west side of Red Canyon in sec. 29, T. 7 S., R. 3 E., contained the following units:

Fall River sandstone:

Description

Thickness (feet)

Sandstone, fine- to medium-grained Not measured

Fuson formation and Lakota sandstone, nndifferentiated:

Covered 22.0

Siltstone, light-gray, very hard 10. 0

Covered 19.0

Sandstone, very fine grained, white. Upper part contains hematitecolored specks and small calcareous concretions.

Sandstone, fine-grained with about 50 percent of interstitial clay of various shades of white, yellow, and maroon

Sandstone, fine-grained, composed of quartz cemented with white clay and silica. Very brittle; breaks into conchoidal flakes

Sandstone, very fine grained, composed of quartz with a minor amount of chert

Sandstone, fine-grained, consists of alternate beds of resistant and friable sandstone that contain abundant pale-green clay cement 


\section{Description}

Fusion formation and Lakota sandstone, undifferentiated-Continued

Sandstone, fine-grained, well sorted, moderate amount of pinkish clay grains and chert. Stained pink to yellow. Very friable

Covered, except for a few exposures of very fine grained sandstone and gray mudstone

Sandstone and interbedded mudstone. Sandstone is fine grained, light gray

Sandstone, fine-grained, light-gray with yellow to brown limonite bands. Minor amounts of clay grains, numerous silt and carbonaceous seams, and scattered large calcareous concretions. Mostly massive, but thin-beded near the top

Covered except for occasional outcrops of interbedded medium-gray

siltstone and very fine-grained sandstone

Sandstone, fine-grained, light-gray with yellowish limonite bands_.---

All of the mineralized rock in the Long Mountain area is in the lower 200 feet of the undifferentiated Fuson and Lakota formations. The principal lithologic units that were penetrated by the drill in these rocks are described below.

Sandstone type 1 is a fine- to very fine-grained, well-sorted sandstone composed predominantly of sub-rounded quartz grains with minor amounts of chert, clay grains, and feldspar. It is light gray, yellow, or pink. In the drilled area it is thick bedded to thinly crossbedded and ranges from 1 to 80 feet in thickness. It is the most prominent and abundant rock type. Those sandstones which under the hand lens appear to contain less than 5 percent of clay grains, rock fragments, and chert grains have been included in sandstone type 1.

Sandstone type 2 is a fine- to coarse-grained, light-gray, pink and brown rock. The degree of sorting decreases as the grain size increases. The composition varies, but the important constituents are subangular quartz, chert, rock fragments, and clay grains and galls. Many of the clay grains contain shards of devitrified volcanic glass. This type of sandstone is found at the base of sandstone type 1, and is interbedded with mudstones. At many localities sandstone type 1 grades into sandstone type 2.

Sandstone type 3 is light to medium gray, very fine grained, and contains appreciable quantities of interstitial clay and silt. Minor amounts of calcareous cement are common. In most places the sandstone contains cross-beds and seams of dark-gray siltstone and carbonaceous material and is interbedded with mudstone. The sandstone rarely exceeds 20 feet in thickness.

Mudstones consisting of siltstone and claystone are abundant as 
fenses interbedded with the various types of sandstones. The siltstones and claystones are generally difficult to separate because of the gradational amounts of silt and the similarity of color, but the overall structural features of these lenses make them a characteristic unit. The mudstones are irregularly interbedded with the sandstones and with thin beds of limestone. The bedding within the mudstones is thinly laminated and commonly distorted. These units are generally carbonaceous, and locally plant remains are abundant. Gypsum-rich veins occur along joints and seams. The mudstones weather to light gray and contain abundant limonite stains. In some places hard laminated dark-gray siltstones weather into thin sheets called "paper shales."

Beds of limestone and sandy limestone up to 2 feet thick are common in the mudstone units. The limestones are aggregates of spherulitic calcite imbedded in a matrix of gray mud. The sandy limestones are light to medium gray and contain abundant fine-grained quartz. In many places these sandy limestones appear to be the extreme edges of lenses of sandstone. Neither type of limestone can be correlated over distances greater than 1,000 feet.

The percentages of the major lithologic units are-

Lithologic type

Sandstone type 1

Sandstone type 2

Sandstone type 3

Mudstone.
Percent of total thickness

44

14

12

30

The distribution of the major types of lithologic units is shown in plates 2 and 3 . These isometric diagrams show the distribution of the lithologic types throughout the explored area. The basal unit of the undifferentiated Fuson and Lakota in the northern and western part is a lens composed predominantly of sandstone of type 1. It is called the lower uraniferous sandstone and is well exposed in the prominent cliffs in Craven Canyon. This sandstone pinches out abruptly east of Craven Canyon and is not found in the southeast part of the mapped area. Overlying this sandstone is a unit composed of interbedded mudstones, limestones, and sandstones of type 3 . Where the lower uraniferous sandstone is missing, this mudstonebearing unit rests upon the Morrison formation. Above this mudstone-bearing sequence is a composite unit made up predominantly of sandstones of types 1 and 2, interbedded with mudstones and sandstones of type 3. This unit is called the "upper uraniferous sandstone." It is approximately 75 feet above the Morrison formation and is continuous throughout the drilled area. Sandstone type 2 is more 
abundant in this unit than in other parts of the undifferentiated Fuson and Lakota.

FAII RIVER SANDSTONE

The Fall River sandstone caps the south end of Long Mountain, where it is a buff, fine- to medium-grained sandstone. The full thickness of the Fall River is not present in the area studied.

\section{STRUCTURAL FEATURES.}

The roeks in the Long Mountain area are only slightly disturbed by faulting and folding. The regional dip is about $21 / 2$ degrees to the southwest and was caused by the Black Hills uplift (see fig. 2). Five faults have been found in the mapped area. Fault 1 (pl. 1) in sec. 18 is a normal fault that trends northeast across the north end of Long Mountain. This fault has a maximum throw of approximately 85 feet. Another fault about 1,200 feet to the north has similar type of displacement. A third fault, a few hundred feet south of fault 1, starts on the west side of Long Mountain, and within 1,600 feet to the northeast attains a throw of about 80 feet. This fault and fault 1 bound a small graben.

Fault .2, in the northwest part of sec. 30 , trends about N. $80^{\circ} \mathrm{E}$., and dies out in the area explored by drilling. Within the mapped area this fault has a maximum throw of about 40 feet. It has been traced to the west of the mapped area for 2,000 feet where it joins a fault that trends N. $45^{\circ}$ E. (Bell and Bales, 1955). A minor northeastwardtrending fault was mapped in the southeast corner of sec. 19.

There are two major joint sets in the area: one strikes N. $20^{\circ} \mathrm{W}$., the other N. $50^{\circ}$ E. (See fig. 2.) Both sets have influenced the formation of the numerous landslides on the borders of the mountain where the Lakota sandstone and Fuson formation have slid into the valleys across the Morrison formation.

Structure contour maps of the southern part of Long Mountain were drawn at the top of the Morrison formation and the base of the upper uraniferous sandstone, using the data obtained from the drill cores. The top of the Morrison formation is a gently undulating surface with a small trough trending southward through the southern part of the explored area. (See fig. 2.) This trough is also outlined by the contours drawn on the base of the upper uraniferous sandstone about 75 feet above the Morrison formation. The lenticular nature of the lower part of this unit makes it necessary to generalize the contours. (See fig. 3.) It is possible that this trough is a flexure and is the last recognizable displacement resulting from movement along fault 2. The fact that the trough is expressed both on the top of the 


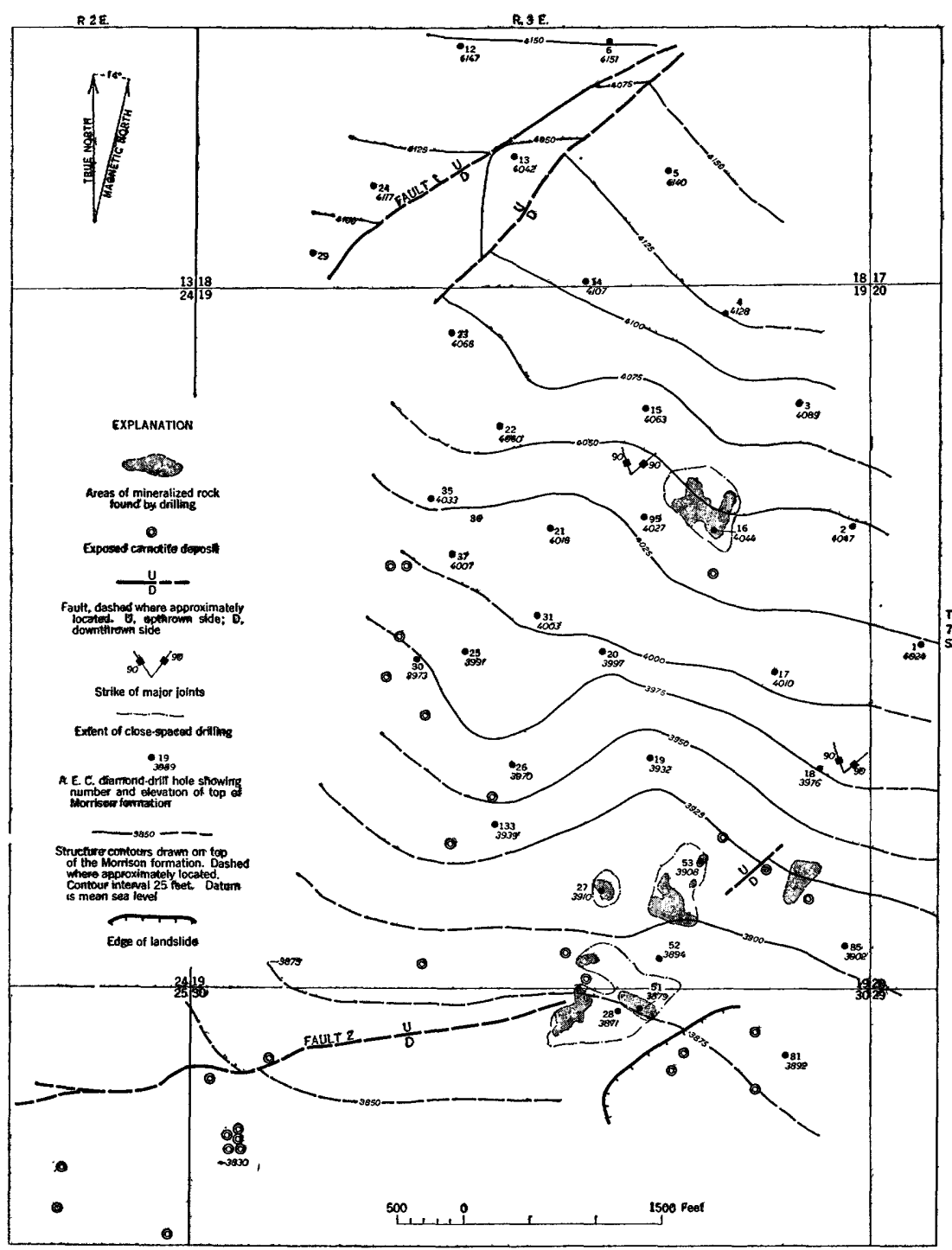

Frgure 2.-Structure contour map, southern part of Long Mountain. Contours drawn on the top of the Morrison formation.

Morrison, and on the base of the upper uraniferous sandstone indicates that it is a flexure rather than two superposed channels.

\section{ORE DEPOSITS}

Prior to 1954, uranium had been produced from nine claims on or near Long Mountain. The ore bodies on these claims have not been studied in detail and in this report will be discussed only in general 


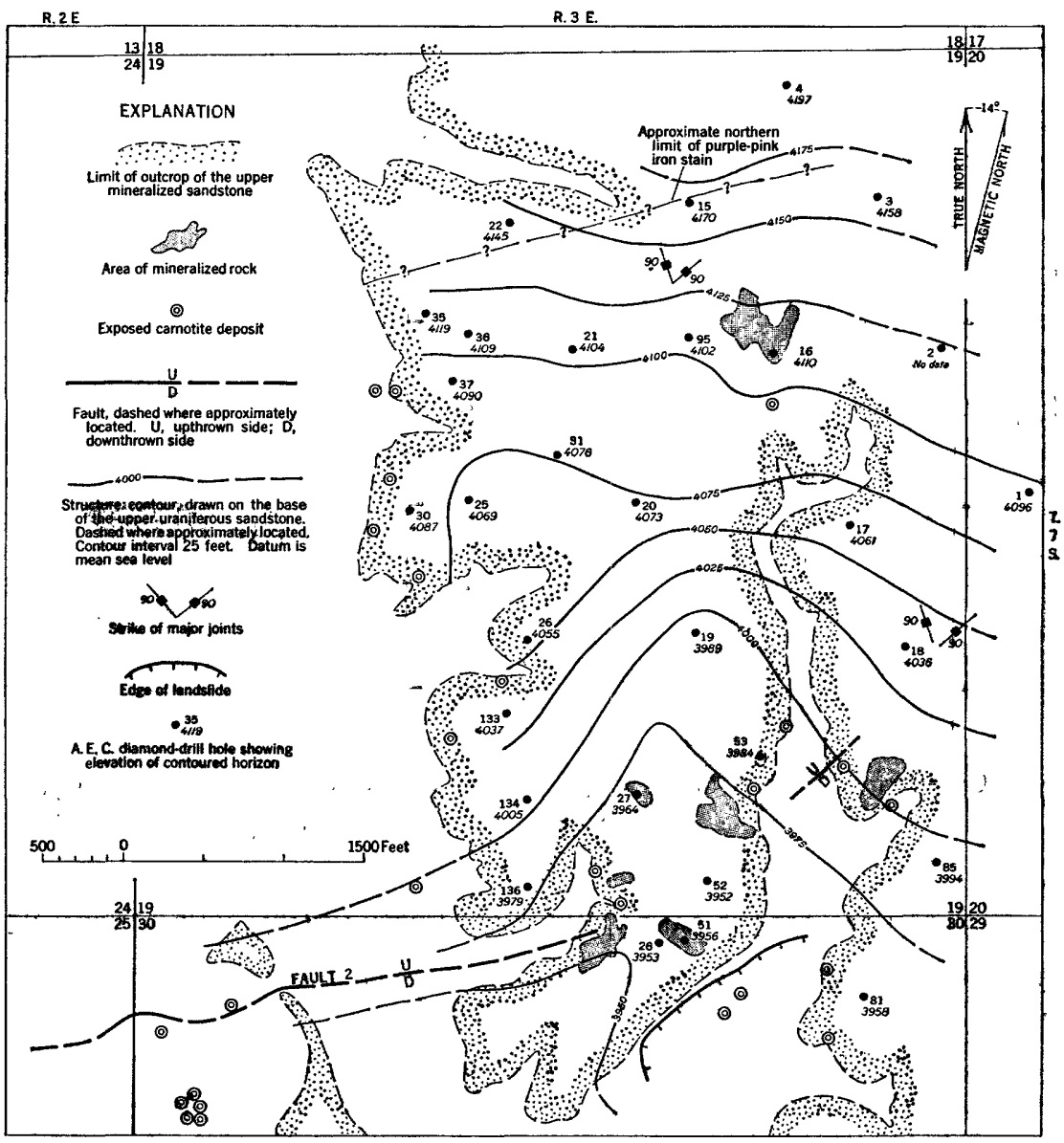

Frgunw 3.-Structure contour map, southern part of Long Mountain. Contours drawn on the base of the upper uraniferous sandstone.

terms. All of the known mineralized rock found on Long Mountain occurs either in the upper or the lower uraniferous sandstone. About equal amounts of ore had been produced from each sandstone unit up to January 1, 1954. The ore was produced from the lower unit only on the Pictograph Mesa and from the upper unit on the Clarabell, Flora, and the Gertrude claims. Personnel of the U. S. Atomic Energy Commission discovered several bodies of uranium ore in the upper sandstone unit during their exploration of the area. All the known carnotite deposits contain relatively low amounts of vanadium in comparison with their uranium content; the ratio is slightly higher in the deposits in the upper sandstone, as illustrated in figure 4. 
